\title{
SPECIES DIVERSITY OF SEGETAL PLANT COMMUNITIES IN THE EARLY NEOLITHIC SETTLEMENT AREA OF THE ŚLĘŻA LANDSCAPE PARK
}

\author{
JADWIGA ANIOŁ-KWIATKOWSKA, ZYGMUNT KĄCKI \\ Department of Biodiversity and Plant Cover Protection \\ Institute of Plant Biology, University of Wrocław \\ Kanonia 6/8, 50-328 Wrocław, Poland \\ e-mail: aniolj@biol.uni.wroc.pl
}

(Received: January 10, 2006. Accepted: March 21, 2006)

\begin{abstract}
The paper contains results of investigations carried out in crop fields within the protected area, which is an important refuge of species diversity in grounds dominated by large-area farms. The segetal vegetation is represented by 13 plant communities, the development of which is influenced by various tillage manipulations. As a result, the segetal flora of the Ślęża Landscape Park is heavily threatened and the structure and species richness of phytocoenoses are distinctly transformed. This is reflected in the frequency of weed occurrence in crops (i.e. there is a small group of common species and a very numerous group of species with 1 or 2 localities), as well as in values of biocoenotic indicators, e.g. the values of diversity indicator $\mathrm{H}$ vary between 1 and 3.5. An analysis of archaeophytes participation (frequency and numbers) in ATPOL squares indicates their significant connection with archaeological sites of the Neolithic settlement. Particular adherence to the early Neolithic settlement areas shows a group of species from the Caucalidion alliance. The richness and diversity of the Park vegetation, conditioned by many hundreds of years of agriculture, are now strongly transformed and have become impoverished. Establishing the Landscape Park, in order to preserve the natural-landscape character of the environment and its cultural and historical values, does not ensure the protection of both the species and the phytocoenotic diversity of this area.
\end{abstract}

KEY WORDS: segetal flora, weed communities, Ślęża Landscape Park, endangered species, species diversity, early Neolithic settlement.

\section{INTRODUCTION}

The Ślęża Landscape Park is one of twelve landscape parks in the Lower Silesia Province and was established in order to protect and preserve the natural and landscape environment of the Ślęża Massif and its valuable culture and historical aspects. The area of the Park is 8,190 hectars (without a buffer zone) and comprises three differentiated units: the Ślęża Massif, the Kiełczyńskie Hills and the Mount Jańska. According to the typological classification of protected areas, the Park has been given the status of an agricultural-forest area, where about $30 \%$ of its area is covered by arable land. The terrain of the Ślęża Park is an old culture region, which is rich in relicts from the past. The oldest traces of humans date back to early Palaeolithic ages and the Lusatian culture, meanwhile settlements have been present here from the beginning of the early Neolithic period (Kulczycka-Leciejewiczowa 1993). These events have led to the essential importance in differentiation of segetal vegetation in the Park. The study was carried out to supply documentary evidence of the floristic richness of the field phytocoenoses within this area and to discover the interdependence between the segetal vegetation and settlement history. The results obtained have provided answers to the following questions:

1. What is the real differentiation of ground-vegetation in farms within the Ślęża Landscape Park?

2. Does this area create a refuge for segetal flora, particularly for its archaeophytic elements?

3. Has the early Neolithic settlement influenced speciesrichness of field habitats?

4. Does there exist any weed species of greater affinity in the areas covering the early Neolithic settlement localities?

\section{MATERIAL AND METHODS}

The object of the study was the segetal vegetation of the protected area occurring in various types of agricultural 
crops. Research sites were selected according to the principle of proportional-participation with the following elements: crop type, size of field, type of land use, and size of chosen plant patch. Field data were collected mainly in the vegetative season of 2004; however, older materials from the period of 1985-2000 were taken into account as well. Plant-cover surveys were usually made on patches with an area of $100 \mathrm{~m}^{2}$, using the Braun-Blanquet method with a seven-degree quantitative scale. The gathered material (comprising 125 relevés) was submitted to a hierarchical numerical classification by the TWINSPAN program (Hill 1979 ) in order to separate groups of communities with the greatest floristic similarity. On the basis of floristic similarity, and the presence of diagnostic species, a syntaxonomic affiliation was determined, and the names and systematics of segetal communities were taken after Schubert (Schubert et al. 1995) and Matuszkiewicz (Matuszkiewicz 2001). For particular plant patches and syntaxa, the Shannon-Weaver's diversity " $\mathrm{H}$ " index was calculated. Additionally, plant patches were compared considering their " $R$ " species richness. For groups of relevés representing one community type, an average value of both " $\mathrm{H}$ " diversity and " $R$ " species richness indices were calculated, and maximum and minimum values were given as well. The obtained results constituted the basis for evaluation degrees concerning formation and transformation of weed phytocoenoses in the Ślęża Landscape Park; a protected area which above all should preserve the natural values.

The other aspect of investigations which was undertaken was to discover the probable relationship between distribution of archaeological sites of the Neolithic settlements and the occurrence of segetal weeds, especially of those brought there in pre- or early-historical ages (Zając 1979). That problem was analyzed using all available data on the flora of the studied area, also taking into account data from the Distribution Atlas of Plant Species in Poland (Zając and Zając 2001), as well as maps and lists of archaeological localities in Lower Silesia (Kulczycka-Leciejewiczowa 1993). In order to find such connections, floristic and archaeological data were analyzed and attributed to the network of squares measuring $10 \times 10 \mathrm{~km}$, which is in compliance with the Polish ATPOL system (Zając 1978).

An analysis of the segetal flora concerning the share of rare and endangered species made it possible to evaluate the real role of the protected areas in preserving biological diversity, particularly of those impacted by various investment and economic activities.

\section{RESULTS}

Vegetation of the Ślężański Landscape Park is strongly differentiated, both floristically and phytocoenotically. As a result of a numerical classification, 13 types of segetal communities, i.e. 12 plant assemblages and one community with an undetermined syntaxonomic position were identified. The following syntaxa were distinguished: AphanoMatricarietum R.Tx. 1937, Vicietum tetraspermae (Krusem. et Vlieg. 1939) Kornaś 1950, Lathyro-Melandrietum Oberd. 1957, Kickxietum spuriae Krusem. et Vlieg. 1939, GeranioSilenetum gallicae Kornaś (1955) 1968, Holco-Galeopsietum Hilb. 1967, Centunculo-Anthoceretum punctati (Koch 1926) Moor 1936, Echinochloo-Setarietum Krusem. et
Vlieg. (1939) 1940, Galinsogo-Setarietum (R.Tx. et Beck. 1942) R.Tx. 1950, Lamio-Veronicetum politae Kornaś 1950 , Amarantho-Chenopodietum albi (Schub. 1989) in Schub. et al. 1995, Oxalido-Chenopodietum polyspermi Siss. 1950. The greatest number of cereal communities was found in wheat crops that were in full accordance with the structure of sowing within that area. Weed communities of the abovementioned assemblages also developed in corn crops and on stubble fields, and in root-plant crops as well. Communities represented by a small number of relevés were separated in the right column of Figure 1 and 2 to mark their presence only, and to show the values of biocoenotic indices.

In the analyzed data-set, relatively even values of the diversity index " $\mathrm{H}$ " were noticeable. The communities are characterized by a wide spectrum of values of this index and by small and similar average values, which have been calculated for particular syntaxa (Fig. 1). The highest values of the diversity index have had phytocoenoses of root plant assemblages, i.e. Galinsogo-Setarietum and Echinochloo-Setarietum. Similar high values were reached in patches of Lamio-Veronicetum politae and Kickxietum spuriae. These syntaxa communities were only found in a few places and have been represented by a small number of relevés, but are characterized by a huge species richness and by presence in patches of a large number of species characteristic for particular syntaxa of the class Stellarietea mediae. The diversity index shows the lowest minimum value in Aphano-Matricarietum patches, however its average value equaled 2.45 , which is the highest value among cereal phytocoenoses. A considerable range of diversity index "H", from 1.4 to 3.4, characterized the Vicietum tetraspermae phytocoenoses. However, the poor floristic patches or formed-as-facies prevailed there, which determined the lowest average value of " $\mathrm{H}$ " among all cereal weed communities. In turn, comparing the values of the " $R$ " species richness index with the "H" diversity index (Fig. 2) has not revealed any direct dependence between them, but has confirmed an earlier observed tendency of the greater species richness in root-plant assemblages. What is noteworthy is the particularly high " $R$ " value for Lamio-Veronicetum politae patches, and for a very rare segetal assemblage called Kickxietum spuriae.

Flora of the field habitats in the Ślęża Landscape Park comprises 179 vascular and 19 sporiferous plant taxa. The frequency of occurrence of vascular plant representatives has strongly differentiated (Fig. 3). A maximum of large numbers of localities have been detected for Matricaria perforata, Apera spica-venti, Viola arvensis, Centaurea cyanus, and others. On the other hand, as many as 65 plant species have only one or two localities in the studied area. An analysis of the Park flora, in respect of synanthropic types, has revealed the presence of as many as 56 archaeophytes. Among the archaeophytes, is a numerous group of species, which are at present rare, and are connected with neutral or alkaline field habitats and represent a Caucalidion alliance, e.g. Lathyrus tuberosus, Melandrium noctiflorum, Consolida regalis, Euphorbia exigua, Kickxia elatine and Geranium dissectum. An interesting question is the penetration of the crops by a plant species of foreign origin with a kenophyte character (14 species) and their continual survival. The presence of some of the newcomers, such as Bryonia alba, Impatiens parviflora or Solidago canadensis in agricultural cultivations is inconvenient. 


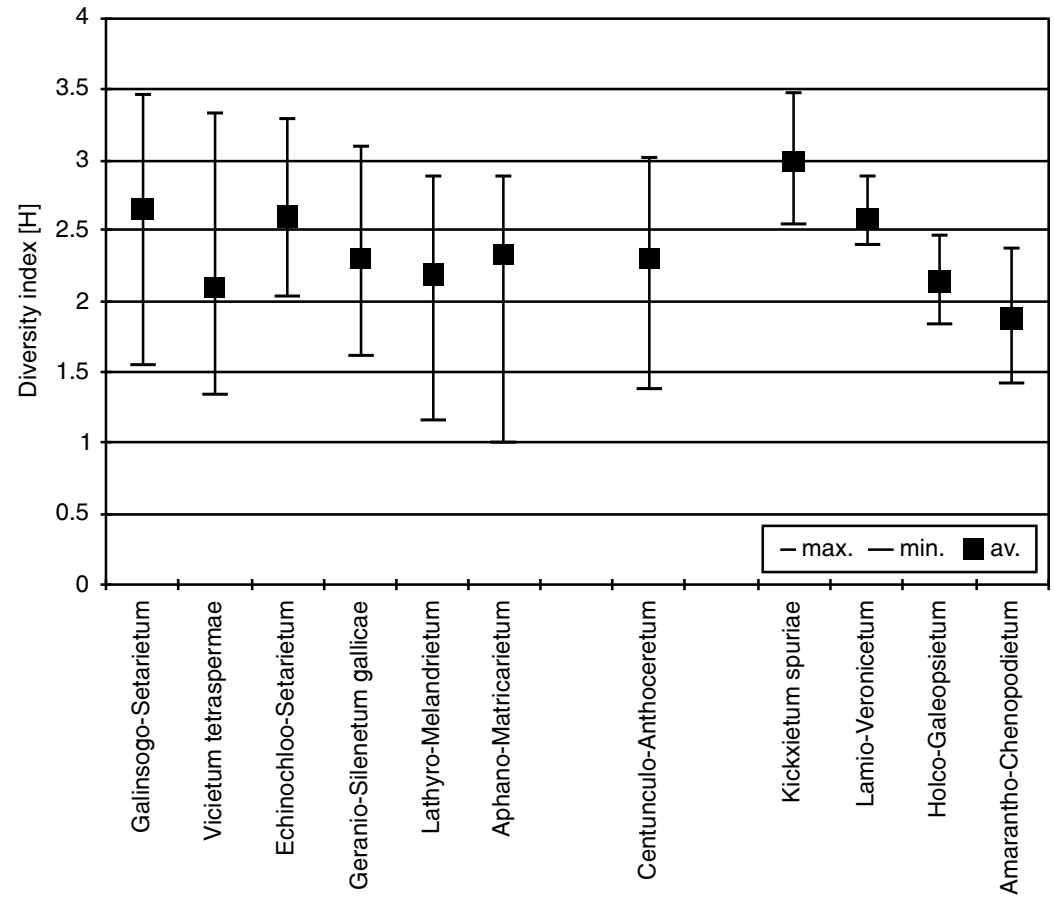

Fig. 1. Range and average values of agrocoenoses' species diversity "H".

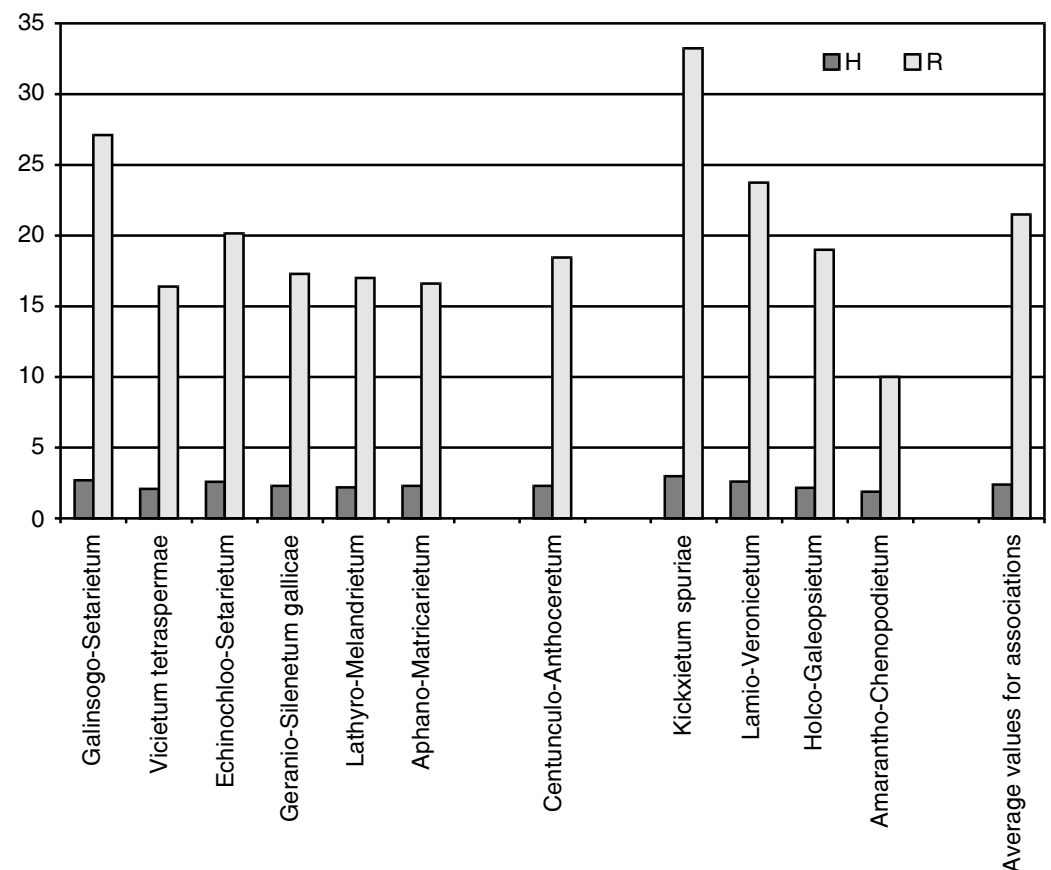

A comparable analysis of distribution of archaeophytes connected, not only with segetal habitats and distribution of historical sites of the early Neolithic settlements, has revealed a relationship between them. Areas of numerous early Neolithic settlements possess richer archaeophyte flora (Fig. 4 and 5). Among the segetal species, the areas of $\mathrm{Ne}-$ olithic settlement indicate localities of species characteristic for a Caucalidion alliance (Fig. 6). On the other hand, areas not settled by primary nations indicate that the flora is poorer in archaeophyte components (Fig. 5).
Fig. 2. Comparison of values of species diversity $(\mathrm{H})$ and species richness $(\mathrm{R})$ index of weed communities of the investigated area.

\section{DISCUSSION}

The segetal vegetation of the Ślęża Landscape Park is strongly transformed. Its change is similar to those observed in many other regions and refers mainly to the decrease in a species' number and to impoverishment of agrocoenoses as a result of agriculture intensification and herbicide application, as well as intensive fertilization (Hilbig 1987; Pyšek and Lepš 1991; Anioł-Kwiatkowska 2003). The complexity of the process of vanishing species is so intere- 


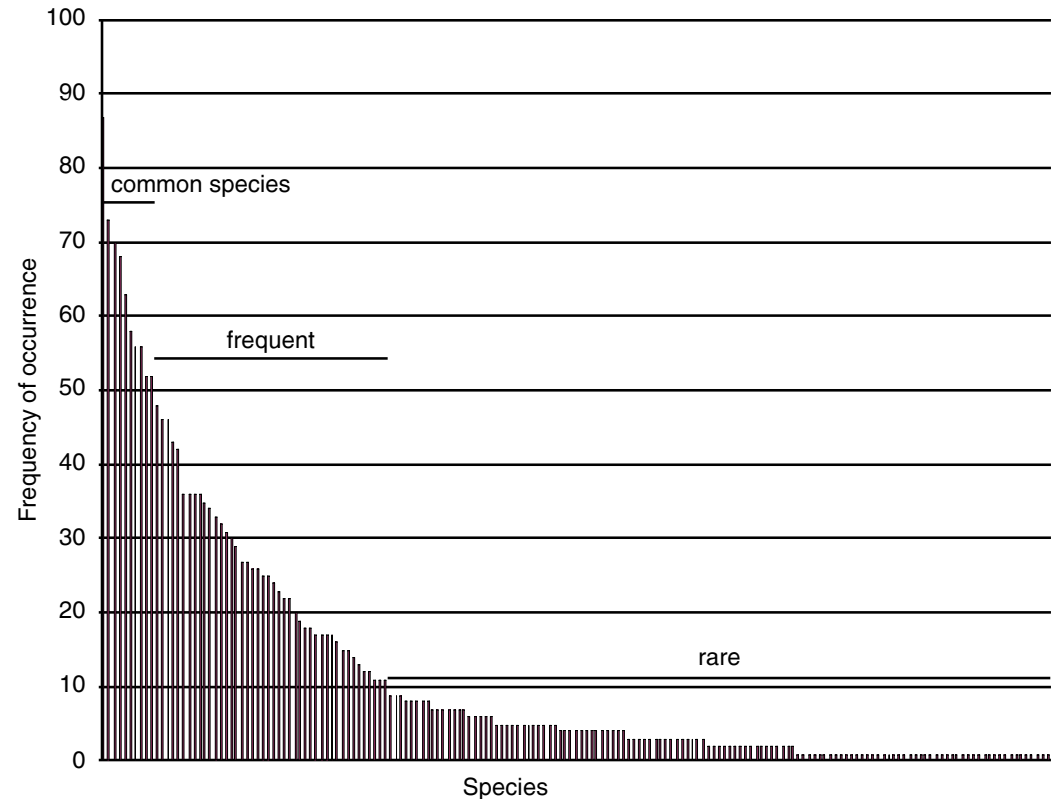

Fig. 3. Frequency of weeds occurrence on fields of the Ślęża Landscape Park. sting and substantial that one must still search for the most important factor playing the decisive role in formation of the species richness (Pyšek et al. 2002). The species diversity of the oldest Neolithic settlement areas in south-western Poland is represented in a very wide range of liminal values, and depending on methods and kinds of cultivation in particular, may assume very high values. However, the difference among the average values of the diversity index, for particular agrocoenoses, seems to be limited intrinsically and moreover, all of the values are low. This fact arouses one's particular interest in relation to the segetal vegetation of lowland locations that should be characterized by

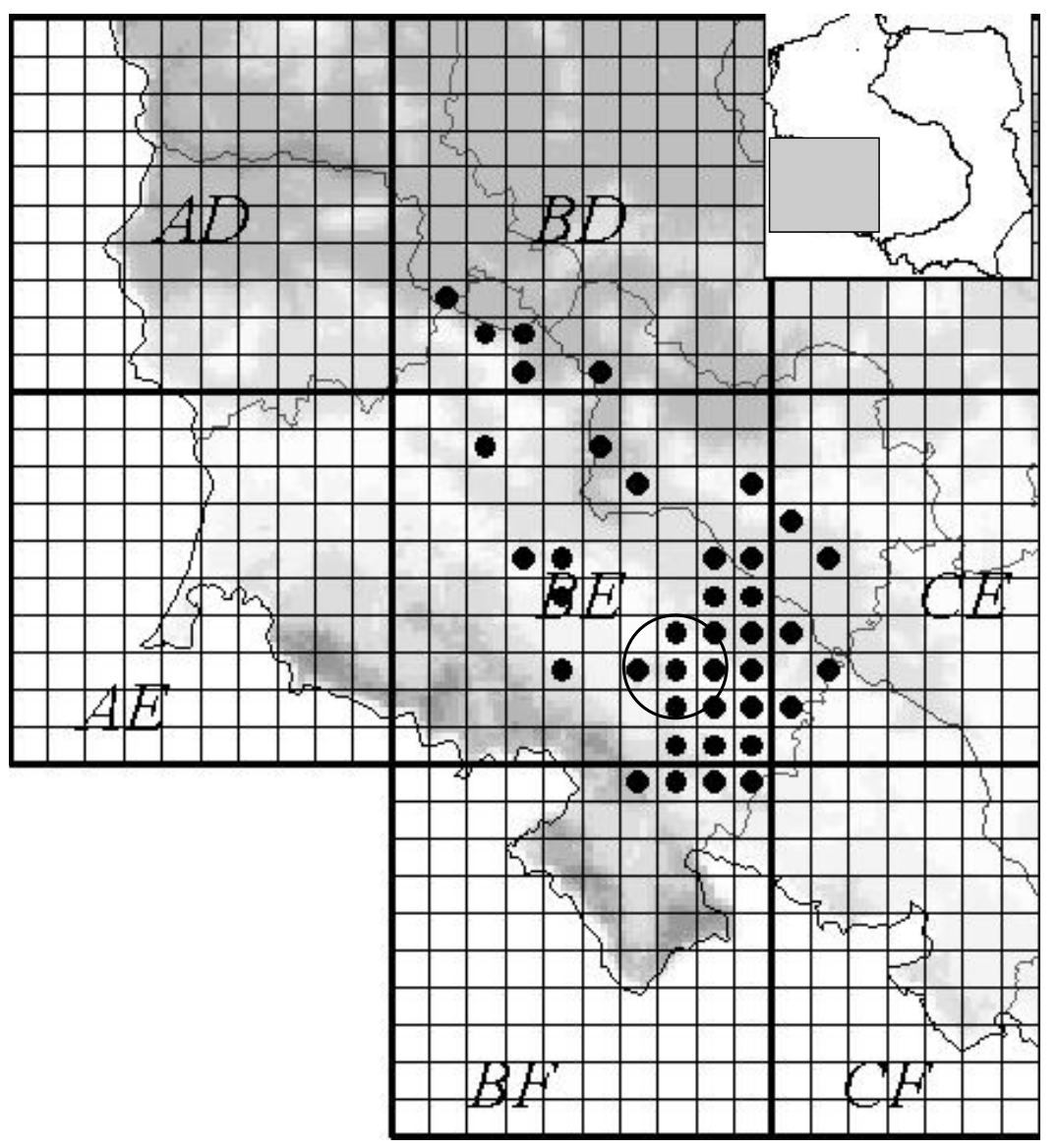

Fig. 4. Distribution of stations of early Neolithic settlements in south-western Poland in ATPOL squares with the research area distinguished (after Kulczycka-Leciejewiczowa 1993 - changes). 


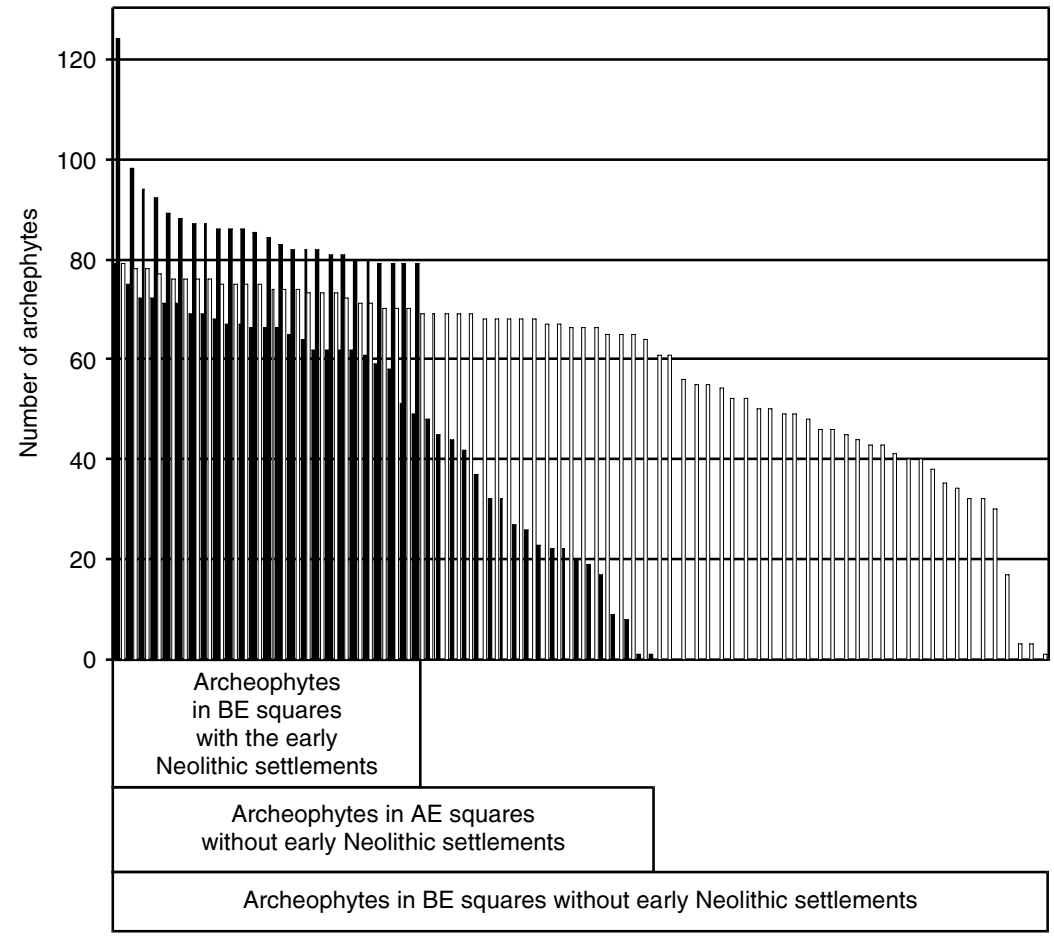

Fig. 5. A numbers of archaeophytes in ATPOL squares $\left(10 \mathrm{~km}^{2}\right)$ in areas with or without the early Neolithic settlements. higher beta-diversity in comparison, for instance with mountain regions (Lososová et al. 2004). This small difference among the average values of the diversity index calculated for the analyzed agrocoenoses may result from the presence of transformed phytocoenoses, which are most often formed as facies, which in turn are built up by a small number of species or without some of the diagnostic species. With respect to time, these features can indicate an impoverishment of species composition and effacement of the difference among particular community types.

Weed communities of cereal crops distinctly become impoverished, presumably with the ones that accompany the crops the most often. Among them, the least number of diagnostic species has been noted in Geranio-Silenetum

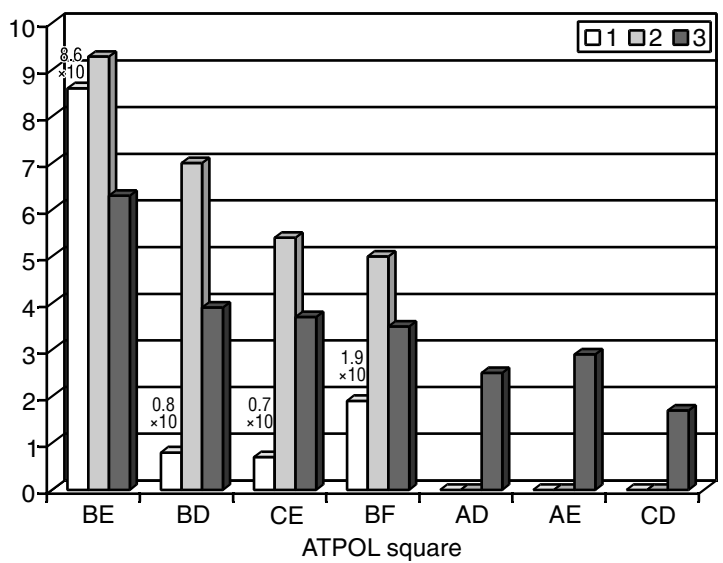

Fig. 6. A number of the early Neolithic settlements in Lower Silesia in ATPOL squares (with a side of $100 \mathrm{~km}$ ) (1) and an average number of species from Caucalidion alliance in squares with (2) or without (3) the early Neolithic settlements. and Vicietum tetraspermae, as well as in Aphano-Matricarietum and Lathyro-Melandrietum patches with a simultaneous increase of the share of accidental species. Among the latter group, the ones of greatest importance are ruderal species and kenophytes. Their participation in agricultural crops has also distinctly increased in other regions (Pyšek et al. 2005). The ruderalization process observed on segetal habitats is strengthened by the possibility of the species' immigration from a neighboring environment and may be the answer to the vacation of a niche occupied hitherto by old weeds, which have been exterminated, for instance by excessive herbicidation. Penetration of neophytes into communities and their relation to the existing components of these communities have already been observed and were extensively discussed by Faliński (1968). In the studied area, a special example of this phenomenon is impoverishment, and then the disappearance of typical root-plant phytocoenoses and formation in their habitats of root-plant communities with kenophytes. Dominant components of such agrocoenoses are the species of two genera: Galinso$g a$ and Amaranthus. Moreover, these communities seem to be a very adapted to crop conditions because in the investigated area they have been characterized quite often by very high species diversity. One may presume that this also results from a specific phenology of the development and growth of root-plants, i.e. from a discontinuance of field work at the end of a vegetative season and a considerably later term of harvest in comparison with cereal crops.

A separate problem, hitherto not undertaken, that may essentially influence a revision of the opinion of reasons for the threat to crop weeds is the evaluation of the degree of their domestication and determining the places of primary introduction in the period of pre-historical migrations of populations. In the studied region, there is the greatest accumulation of the first, i.e. the early Neolithic settlements 
(Kulczycka-Leciejewiczowa 1993). A distinct relationship observed between the occurrence of archaeophytes (a large number of them) and the localities of the early Neolithic settlements indicates that these species have little ability for dispersion and it is possible that these limitations result from habitat conditions. From this fact may rise the difference between diversity and the disappearance of segetal species in warm and moderately cool regions described by Pyšek et al. (2005b). It is also known that warm areas, where the vegetative period is long, have specific physiographical conditions and were preferred by the Neolithic settlers (Kulczycka-Leciejewiczowa 1993). Up to the present, these regions belong to the most afforested and were dominated by cultivable fields. They also create the main refuge for numerous archaeophytes. In a special way, such habitat conditions are preferred by species of the Caucalidion alliance. Most of them, as well as their phytocoenoses, belong to rare or near-extinct elements of vegetation (Anioł-Kwiatkowska 1988a, b; Kącki et al. 1999; Fabiszewski and Kwiatkowski 2002; Lososová 2003). Occurrence of these species seems to be compatible with areas of the early Neolithic settlements. Reasons for their disappearance are presumably both the lack of an inflow of diaspores and the constant decrease of seeds deposited in the soil or in sowing material resulting from refined methods of cultivation. On the other hand, the fascinating element is the permanent existence of these taxa for thousands of years in their locality of introduction.

\section{CONCLUSIONS}

1. The flora and vegetation of the Ślęża Landscape Park is differentiated, yet is distinctly transformed and characterized by low values of the diversity index, which may result from the phytocoenoses impoverishment in diagnostic species for syntaxa (unification of the species composition and of the spatial structure). The high values of species richness in relation to species diversity result from a large participation of accidental species.

2. The Ślęża Lanscape Park, established in order to preserve its natural values, does not fulfill a protecting role for weed vegetation, though there occur numerous groups of rare plant species.

3. The presence of rare and endangered species, especially from the Caucalidion alliance indicates the distant beginning of agriculture development in this region; the greater richness of archaeophytes in places determined as early Neolithic localities has probably resulted from those settlements.

\section{LITERATURE CITED}

ANIOŁ-KWIATKOWSKA J. 1988a. Lathyro-Melandrietum Oberd. 1957 na czarnych ziemiach wrocławskich. Acta Univ. Wrat., Prace Botaniczne 38: 195-205. (in Polish with English summary)

ANIOŁ-KWIATKOWSKA J. 1988b. Rozmieszczenie niektórych interesujących chwastów segetalnych na Dolnym Śląsku. Acta Univ. Wrat., Prace Botaniczne 40: 7-35. (in Polish with English summary)
ANIOŁ-KWIATKOWSKA J. 2003. Zagrożenia flory synantropijnej Dolnego Śląska - problem wymierania archeofitów. [Threatend synanthropic flora of Lower Silesia - problem of extinction of archeophytes]. In: Zagrożone gatunki flory naczyniowej Dolnego Śląska. [Endangered Vascular Plants of Lower Silesia] Z. Kącki (ed.). Instytut Biologii Roślin Uniwersytet Wrocławski, Polskie Towarzystwo Przyjaciół Przyrody "Pro Natura", pp. 151-164. (in Polish with English summary)

FABISZEWSKI J., KWIATKOWSKI P. 2002. Threatened vascular plants of the Sudeten Mountains. Acta Soc. Bot. Pol. 71 (4): 339-350.

FALIŃSKI J.B. 1968. Studia neofityzmu i stosunek neofitów do innych komponentów zbiorowisk [Stages of neophytism and the reaction of neophytes to other components of the community]. In: Synatropizacja Szaty Roślinnej. I. Neofityzm i apofityzm w szacie roślinnej Polski. Faliński J.B. (ed.) Mat. Zakł. Fitos. Stos. UW. 25: 15-29. (in Polish with English summary)

HILBIG W. 1987. Changes in segetal vegetation under conditions of industrialized agriculture. Archiv für Naturschutz und Landschaftsforschung 22: 229-249.

Hill M.O. 1979. TWINSPAN: A FORTRAN program for arranging Multivariate Data in order two-way table by classification of the individuals and attributes. Cornell University, Ithaca, New York. 90 p.

KĄCKI Z., ANIOŁ-KWIATKOWSKA J., DAJDOK Z. 1999. Kickxietum spuriae - nowy dla Polski zespół chwastów segetalnych. Fragm. Flor. et Geobot. Ser. Polonica: 119-125. (in Polish with English summary)

KULCZYCKA-LECIEJEWICZOWA A. 1993. Osadnictwo neolityczne w Polsce południowo-zachodniej. Instytut Archeologii i Etnologii, PAN, Wrocław. 223 p. (in Polish with English summary)

LOSOSOVÁ Z. 2003. Estimating past distribution of vanishing weed vegetation in South Moravia. Preslia 75: 71-79.

LOSOSOVÁ Z., CHYTRÝ M., CIMALOVÁ Š., KROPÁČ Z., OTÝPKOWÁ Z., PYŠEK P., TYCHÍ L. 2004. Weed vegetation of arable land in Central Europe: Gradients of diversity and species composition. J. Vegetation Sci. 15: 415-42.

MATUSZKIEWICZ W. 2001. Przewodnik do oznaczania zbiorowisk roślinnych Polski. PWN, Warszawa. 537 p. (in Polish)

PYŠEK P., JAROŠÍK V., CHYTRÝ M., KROPÁČ Z., TYCHÍ L.,WILD J. 2005a. Alien plants in temperate weed communities: prehistoric and recent invaders occupy different habitats. Ecology 86 (3): 772-785.

PYŠEK P., JAROŠÍK V., KROPÁČ Z., CHYTRÝ M., WILD J., TYCHÍ L. 2005b. Effects of abiotic factor on species richness and cover in Central European weed communities. Agriculture, Ecosystems and Environment 109: 1-8.

PYŠEK P., KUČERA T., JAROŠÍK V. 2002. Plant species richness of nature reserves: the interplay of area, climate and habitat in central European landscape. Global Ecol. Biogeogr. 11: 279-289.

PYŠEK P., LEPŠ J. 1991. Response of a weed community to nitrogen fertiliziation: a multivariate analysis. J. Vegetation Sci. 2: 237-244.

SCHUBERT R., HILBIG W., KLOTZ S. 1995. Bestimmungsbuch der Pflanzengesellschaften Mittel- und Nordostdeutschlands. Gustav Fischer Verlag, Jena-Stuttgart. 403 p.

ZAJĄC A. 1978. Atlas of distribution of vascular plants in Poland. Taxon 27 (5-6): 481-484.

ZAJĄC A. 1979. Pochodzenie archeofitów występujących w Polsce. Uniwersytet Jagielloński Kraków, Rozpr. hab. 29 pp. 1-213. (in Polish)

ZAJĄC A., ZAJĄC M. (ed.) 2001. Atlas rozmieszczenia roślin naczyniowych w Polsce. Nakładem Pracowni Chorologii Komputerowej Instytutu Botaniki Uniwersytetu Jagiellońskiego, Kraków. 715 p. (in Polish and English) 